\title{
NON-STANDARD MONETARY POLICIES IMPLEMENTED BY THE EUROPEAN CENTRAL BANK AFTER THE FINANCIAL CRISIS*
}

\author{
Meryem FILIIZ BAŞTÜRK**
}

\begin{abstract}
The financial crisis which began in the U.S. in 2007 influenced all economies on a global scale following the collapse of Lehman Brothers in September 2008. As a response to the crisis, central banks started to implement non-standard monetary policy tools as well as short-term interest rates also known as standard policy tools in order to help monetary policy transmission channels work effectively. The European Central Bank (ECB) implemented non-standard monetary policies as in addition to the standard policy tools during this period. The non-standard monetary policies introduced by the ECB were different from those implemented by other central banks (Fed, Bank of England) in terms of implementation and results. Firstly, the policies of the ECB were not specific to one single country. Secondly, the banking system was the major source of finance in Europe, which had an impact on the policies. In this regard, the ECB introduced a policy of enhanced credit support consisting of five main elements in order to maintain price stability over the medium term following the crisis. By 2010, public debt in some member countries of the European Union reached high levels, requiring them to take additional measures. The Securities Markets Programme was introduced to that end. Initially focusing on the debt securities of Greece, Ireland, and Portugal, the Securities Markets Programme was expanded in August 2011 to cover the debt securities of Italy and Spain. In addition, two Long-term Refinancing Operations (LTROs) were introduced. This article presents a descriptive analysis of the non-standard monetary policy tools introduced by the ECB following the financial crisis. However, the monetary policy implemented in the Euro zone is not specific to one single country, and every country has a different financial structure, both of which limit the effectiveness of the policies

* Date of Submission: 11.04.2016; Date of Acceptance: 14.02.2017

This study is the expanded version of a paper presented at International Istanbul Finance Congress 2013 but not published.

** Uludag University, Faculty of Economics and Administrative Sciences, Asst. Prof. Dr.
\end{abstract}


implemented. The changing structure of the monetary policy implemented in the aftermath of the crisis aims to help the transmission channel work effectively. This depends on countries' having a strong budget and financial structure as well as an effective monetary policy. Therefore, general economic factors may have complicated impacts on shaping the expected results of the policies when there are various implementations of monetary policies.

Keywords: Non-standard Monetary Policy, The European Central Bank, Financial Crisis

\section{FINANSAL KRIZZIN ARDINDAN AVRUPA MERKEZ BANKASI TARAFINDAN UYGULANAN GELENEKSEL OLMAYAN PARA POLITIIKALARI \\ Öz}

2007 yılında ABD’de başlayan finansal kriz 2008 Eylül ayında Lehman Brothers’ın iflasının ardından küresel ölçekte bütün ekonomileri etkisi altına almıştır. Krize cevap olarak merkez bankaları tarafından para politikasının ekonomiye aktarım kanallarının etkin bir şekilde çalışmasını sağlamak amacıyla geleneksel politika aracı olarak da nitelendirilen kısa vadeli faiz oranları yanında geleneksel olmayan para politikası araçları da kullanılmaya başlanmıştır. Avrupa Merkez Bankası (ECB) da bu dönemde geleneksel politika aracının yanında geleneksel olmayan para politikaları da uygulamıştır. Ancak ECB tarafından uygulanan geleneksel olmayan para politikaları, uygulama ve sonuçları itibarıyla diğer merkez bankası örneklerinden (Fed, Bank of England) ayrışmaktadır. İlk olarak ECB’nin uyguladığı politikalar tek bir ülkeye özgü değildir. İkinci olarak Avrupa'da bankacılık sisteminin temel finansman kaynağı olması, uygulanan politikalarda etkili olmuştur. Bu doğrultuda ECB tarafından finansal krizin ardından orta vadede fiyat istikrarını sağlamak için beş temel bileşenden oluşan arttırılmış kredi desteği politikası uygulamaya konulmuştur. 2010 yılına gelindiğinde Avrupa Birliğine üye bazı ülkelerin kamu borçlarının yüksek seviyelere ulaşması ek önlemlerin alınmasını gerektirmiştir. Bu amaçla Menkul Kıymet Piyasaları Programı devreye sokulmuştur. Başlangıçta Yunanistan, İrlanda ve Portekiz' in borçlanma senetlerini içeren program, Ağustos 2011'de İtalya ve İspanyảnın borçlanma senetlerini de kapsayacak şekilde genişletilmiştir. Ayrıca Aralık 2011 ve Şubat 2012'de iki tane LTRO uygulamaya konulmuştur. Bu çalışmada finansal krizin ardından ECB tarafından uygulamaya konulan geleneksel olmayan para politikası araçları betimsel olarak incelenmektedir. Ancak Euro bölgesi özelinde uygulanan para politikasının tek bir ülkeye özgü olmaması ve ülkelerin farklı mali yapılara sahip olması uygulanan politikaların etkinliğini kısıtlamaktadır. Krizden sonraki süreçte uygulanan para politikasının değişen yapısı aktarım mekanizmasının etkin bir şekilde çalışmasını amaçlamaktadır. Bunun başarılması da etkin bir para politikası yanında, ülkelerin sağlam bütçe ve mali yapılara sahip olmasına bağlıdır. Dolayısıyla para politikalarının çeşitlenen uygulamalarında, genel ekonomik faktörler politikalardan beklenen sonuçların şekillenmesinde karmaşık etkiler yapabilmektedir.

Anahtar Kelimeler: Geleneksel Olmayan Para Politikası, Avrupa Merkez Bankası, Finansal Kriz 


\section{INTRODUCTION}

Just like the previous crises, the economic crisis starting in the U.S. in 2007 was preceded by a period when asset prices increased sharply, long-term credits expanded, risky credits resulting from low risk premium and liquidity abundance were financed. However, what differentiated this crisis from the previous ones was that it gained a global dimension as it affected all the economies. The factors making the crisis of 2007 different are that the financial innovations that rapidly emerged in recent years have made markets interdependent and that financial markets in developed countries have not been adequately monitored or supervised then (Claessens, et al. 2010:4-7).

Central banks responded to the crisis starting in August 2007 but turning into a global crisis in September 2008 with the collapse of Lehman Brothers by adopting standard and non-standard monetary policy tools. During the "Great Moderation", there was a kind of agreement among countries on the implementation of monetary policy, and short-term interest rates were adopted as policy tools. However, this standard policy tool was inadequate during the crisis. Like many central banks, the European Central Bank (ECB) also adopted non-standard monetary policy tools. However, these tools differ from one another in terms of the structure of financial systems and the functionality of transmission channels.

The central banks of developed countries took various measures as a response to the financial crisis of 2007. It is possible to see different classifications in studies analyzing non-standard monetary policies adopted by developed countries. For example, Lenza, et al. (2010) analyzed non-standard monetary policies under two categories: the policies before and after the collapse of Lehman Brothers. A similar classification was adopted by Cecioni, et al. (2011) and Thronton (2012). However, when the Euro area is considered, an additional classification is also required since additional measures came up in May 2010 when public debt levels of some member countries of the Euro area reached quite high levels. In the reports prepared by the ECB, the crisis is analyzed under four periods (ECB, 2010a:63; ECB, 2011:57). Their classification focused on the policies adopted before and after the collapse of Lehman Brothers, removal of some non-standard policies, and the emergence of sovereign debt crisis (ECB, 2010a:63; ECB, 2011:57). This paper, though, adopts an analysis of three categories since the policies which were abolished or which authorities decided to abolish were adopted again with the emergence of the sovereign debt crisis. Following Cassola, et al. (2010), Lane (2012), Trichet (2013) and Drudi, et al. (2012), this paper firstly analyzes the measures taken between August 2007 and September 2008, and between September 2008 and May 2010. Then it focuses on the policies adopted by the ECB to solve the public debt problem of some countries.

Discussing the impacts of non-standard monetary policy tools adopted by the ECB during the crisis, this paper continues as follows. Section 2 examines transmission channels 
in the Euro area prior to the crisis. Section 3 reviews the studies focusing on the effectiveness of non-standard monetary policy tools. Section 4 analyses non-standard monetary policy tools adopted by the ECB as a response to the crisis starting in August 2007 in the U.S. but gaining a global dimension in September 2008 following the collapse of Lehman Brothers. Section 5 analyzes the impact of fiscal condition on monetary policies.

\section{TRANSMISSION CHANNELS IN THE EURO AREA PRIOR TO THE CRISIS}

The main goal of the ECB is to ensure price stability in the medium term. In line with this goal, target inflation was set "below 2 percent but close to that percent" (Trichet, 2013:232). To achieve this goal, the ECB adopted a two-legged strategy: economic analysis and monetary analysis, which are complementary (ECB, 2010c:64). Economic analysis tries to identify risks to price stability in the short term by following the real activity and financial developments in the economy. Monetary analysis, though, aims at crosschecking the economic analysis in the medium and long term by focusing on medium and long term risks to price stability (Scheller, 2006:83-85).

The effectiveness of the monetary policy adopted by the ECB to ensure price stability depends on whether transmission channels work properly or not. Monetary transmission mechanism, which describes monetary policy decisions affects total demand and inflation, works within various channels. But for the transmission channels to work, a change in policy interest rate must affect market interest rate (Taylor, 1995:11). The transmission mechanism that consists of interest rate channel, credit channels, exchange rate channel and asset prices channel works effectively with interest rate channel in the Euro area (ECB, 2010a:60; ECB, 2010b:85-86). Exchange rate channel, though, is less effective in a big closed area like the Euro area when compared to small and open economies (Scheller, 2006:79).

Banks in the Euro area have an important role in the transmission of monetary policy. With the help of banks, monetary policies affect aggregate demand and inflation via various channels, which are interest rate channel, credit channels and risk-taking channel (ECB, 2009a:66). The table below presents a schematic overview of these channels, and they are then explained one by one. 


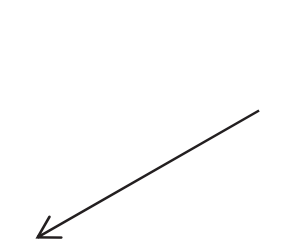

\section{Change in Monetary Policy}

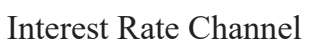

Credit Channel
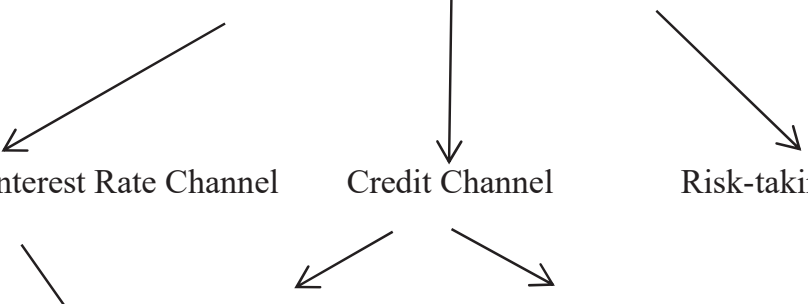

Risk-taking Channel

Bank Lending Channel Balance Sheet Channel
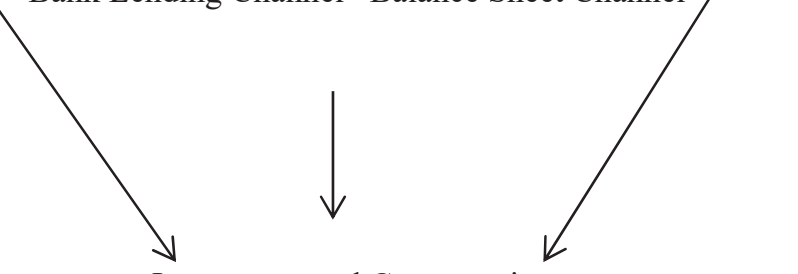

Investment and Consumptiom

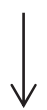

Aggregate Demand and Inflation

Figure 1. Monetary Transmission Channels

Source: ECB, 2009a: 66

Through the interest rate channel, made up of two stages, short-term nominal interest rates affect long-term real interest rates via sticky wages and expectations theory. Long-term real interest rates that have a decisive impact on the decisions of households and firms about consumption and investment have an impact on aggregate demand and inflation (Egert and MacDonald, 2009:280). Banks, with their large share, have an influential role in the financial system within the Euro area. Thus, the bank interest rate pass-through is a main determinant of the interest rate channel (ECB, 2008:86). The interest rate channel, here, affects the demand for bank loans (ECB, 2009a:65). However, the financial crisis weakened the transmission from interest rates used as a policy tool to money market interest rates and bank interest rates (ECB, 2011:56).

The credit channel is composed of bank lending channel and balance sheet channel. According to the bank lending channel developed by Bernanke and Blinder (1988), the deposits 
of banks in their liability accounts decrease as a result of a contractionary monetary policy. A decrease in deposits leads to a decline in bank loans kept in banks' asset accounts and slows down the economy, thereby affecting the aggregate demand and inflation. For this channel to work, though, the decrease in bank deposits is required not to be compensated with securities (Bernanke and Blinder, 1992: 918-19). The balance sheet channel analyzes the impact of changes in monetary policy on the financial positions of borrowers (Cecchetti, 1995:85-86).

Financial innovations, however, have become more common in today's world, which has increased securitization and introduction of new financial tools. As a result, access to different financial sources has become easier, and the dependence on bank loans has decreased (Bernanke and Gertler, 1995:42). As financial innovations increased the risk-taking attitudes of banks, a new channel was added to the transmission channel. Through the risk-taking channel, low short-term interest rates enhance risk-taking potential of banks in various ways. First, low interest rates make risky assets more attractive to all investors. Second, banks also finance risky projects by lending more than necessary when interest rates are low and there is an abundance of liquidity (ECB, 2008:87; ECB, 2009a:68). All these developments made the bank lending channel less effective in the Euro area before 2007 (ECB, 2010b:8990). In line with this view, Altunbaş, et al. (2009) argued that securitization increased after euro was adopted as the single currency, and that bank lending channel weakened in the Euro area, as a result. This was explained based on two mechanisms. First, as asset securitization increases the liquidity of banks, the financial need of banks decreases when there is a contractionary monetary policy. Secondly, it gives banks an opportunity to canalize a specific amount of credit risk to markets.

The monetary transmission mechanism lost its function in the second quarter of 2007 with the outbreak of the economic crisis of 2007 in the U.S. Starting in August 2007 as a subprime mortgage crisis, it turned into a liquidity crisis in a short period of time and spread to all other countries. This crisis affected the Euro area via two mechanisms. First, the banks operating in the area were affected by the crisis as they invested in mortgage-backed securities. Secondly, banks largely stopped providing their counterparts with funds in the interbank money market in such an uncertain environment. This ended up with decreasing transactions in interbank money market (Fahr, et al. 2011:26).

\section{LITERATURE REVIEW}

The impacts of non-standard monetary policies in the Euro area were categorized in the relevant studies as those before and after the emergence of the European Sovereign Debt Crisis.

The empirical studies analyzing the effects of non-standard monetary policies in the Euro area agree on the fact that the policies implemented yield positive results. These studies, 
however, generally focused on the period before May 2010. In other words, they analyzed the effectiveness of policies implemented in some countries within the Euro area for the period when the public debt problem did not emerge yet. In this regard, Lenza et al. (2010) analyzed the impacts of non-standard monetary policies in the Euro area for the period between November 2008 and August 2009 by using B-VAR model. They indicated that the policies implemented had an impact on the real economy with some delay. They also emphasized that its impact on the inflation was also delayed. They concluded that non-standard monetary policies had remarkable positive impacts on the financial sector and economy. Peersman (2011) analyzed the impacts of non-standard monetary policies for the 1999-2009 period by using structural vector autoregressive (SVAR) methodology. Peersman claimed that standard and non-standard monetary policy shocks had significant and similar effects on the economic activity and inflation. But, he emphasized that the impact of non-standard monetary policy on output and inflation was slower and noted that the transmission mechanism worked differently for each policy tool. Fahr, et al. (2011) analyzed the transmission of non-standard policies into economy by using structural vector autoregressive (SVAR) model. They concluded that the policies implemented supported the standard monetary policy and decreased the financial shocks faced in banking system. In their study Giannone, et al. (2011), argued that the non-standard monetary policy measures used after the collapse of Lehman Brothers were effective and promoted the credit expansion and economic activity. But they also emphasized that the policies did not offer permanent solutions to the structural problems in the financial sector. Abbasi and Linzert (2011) claimed that the transmission from policy interest rates to market interest rates weakened because of the liquidity shortage that emerged in the money market after the financial crisis and of the resulting uncertain environment and noted that the standard monetary policies failed then. They stated that the non-standard monetary policies implemented as of September 2008 made the first stage of the transmission effective again. They concluded that the policies decreased the money market interest rates that sharply increased after the crisis. Cassola, et al. (2010) analyzed the relation between the measures taken by the ECB and the monetary market interest rates by using the unrestricted vector autoregressive (VAR) model for the period between 2007 August and 2010 October. They claimed that the non-standard monetary policies implemented by the ECB contributed to decreasing money market spreads and liquidity premium.

Different from other studies, the study by Pattipeilohy, et al. (2013) focused on the period after the emergence of the sovereign debt crisis. This study analyzed the effectiveness of the Securities Market Programme (SMP) and the extended liquidity provision (LTRO). The authors claimed that LTRO interventions had short-term impacts on government bond yields and that the expansion of SMP to cover Italy and Spain in August 2011 had a remarkable impact on the government bonds but this impact came to an end in a few weeks. In their study, Darracq-Paries and De Santis (2013) analyzed the macro-economic effects of long-term 
refinancing operations (LTROs) introduced by the ECB in December 2011 and February 2012. They stated that the non-standard monetary policy improved the banks' conditions for loans and prevented a sudden decrease in loan supplies. They also claimed that the policy enhanced the standard interest rate policy. Boeckx, et al. (2014) analyzed the effectiveness of the non-standard monetary policies implemented by the ECB for the period 2008-2013 by using SVAR methodology. They analyzed the exogenous innovations to the balance sheet of the ECB. They concluded that an increase in the ECB's balance sheet led to an increase in outputs and prices in the Euro area. In this regard, they argued that the non-standard monetary policy tools that expanded the balance sheet of the central bank had an impact on the economy. They also studied the impacts of balance sheet shocks on the variables of the financial market and the banking sector. They claimed that an increase in the balance sheets of the ECB improved the conditions of households and firms for borrowing from banks and affected the financial stability. Finally, the impact of balance sheet shocks on the output and prices was separately analyzed for each country in the Euro area. They concluded that the impact on prices was quite similar among countries but the impact on output was different. It was particularly emphasized that the impact on output was insignificant in countries that were more affected by the crisis. In her study, Szczerbowicz (2015) analyzed the impacts of non-standard monetary policies implemented by the ECB on the borrowing costs of banks and governments. The study argued that three-year LTROs and lowering deposit rate to zero defused the tensions in the monetary markets and central bank interventions had a decreasing impact on the re-borrowing costs of the banks and governments that existed particularly in countries at high risk.

Although econometric analysis concluded that the policies implemented by the ECB were effective, it should be noted that there was some uncertainty about the long-term impacts of non-standard monetary policies in general since such policies may lead the investors to take too much risk in financial markets when the interest rates are at low levels. Also, non-standard monetary policies leading to the expansion of the balance sheets of central banks may have an inflationist pressure on monetary policies (Peersman, 2014:13-14).

\section{NON-STANDARD MONETARY POLICIES ADOPTED BY THE EUROPEAN CENTRAL BANK}

After the adoption of Euro as the single currency by the EU members, the European Central Bank was assigned the task of pursuing the monetary policy by the member countries of the Euro area. The ECB was established to implement the monetary policy as an independent institution (Scheller, 2006:41-43). This makes the ECB different from the other central banks of developed countries as the policies implemented by the ECB are not specific to a single country unlike what is observed in other countries (like US, Japan, and Canada) 
(De La Dehesa, 2013:52). Essentially, it is important to consider two factors while evaluating the monetary policies adopted by the ECB to fight against the financial crisis. The first one is the impact of the specific conditions and differences in the institutional structure of the EMU (Economic and Monetary Union). The second one is that the Euro area has remarkable financial differences when compared to other big economies, which cannot be ignored (Cour-Thimann and Winkler, 2013:5-7).

The central banks of developed countries took several measures against the crisis that gained a global dimension after the collapse of the Lehman Brothers in September 2008, affecting all economies. Since banks in the Euro area have an important role in the transmission of monetary policy, the ECB introduced the policy of enhanced credit support to enable banks to regain this function. In early 2010, the Securities Markets Programme was put into effect as some uncertainties started to emerge on financing public debt in some member countries in the Euro area. Initially focusing on the debt securities of Greece, Ireland, and Portugal, the Securities Markets Programme was expanded in August 2011 to cover the debt securities of Italy and Spain. In addition, the Outright Monetary Transaction (OMT) was announced; two Long-term Refinancing Operations (LTROs) were introduced, and open-ended forward guidance was adopted by the ECB (Eser and Schwaab, 2016:164). All these non-standard monetary policy tools introduced by the ECB are independent of standard monetary policy tools and aim to make standard policy tools functional in the markets again. They were adopted for a temporary period to realize this goal (Trichet, 2013:238). These monetary measures introduced by the ECB against the crisis were analyzed under three periods following Cassola, et al. (2010), Lane (2012), Trichet (2013) and Drudi, et al. (2012).

\section{IV.1. Financial Turmoil (2007August - 2008 September Period)}

During the period between August 2007 and September 2008, the first phase of the financial crisis, the central banks of developed countries supported the markets by changing not the size but the compositions of their balance sheets (Lenza, et al., 2010:302). The mortgage crisis starting in the U.S. affected the Euro area since the banks operating in the area had invested in mortgage-backed securities. Moreover, the banks largely stopped funding their counterparts in the interbank money market in the emerging uncertain environment. This led to a liquidity shortage in the interbank money market. The European Central Bank was one of the first bank intervening in the market then and provided banks with liquidity to meet their financial needs (Fahr, et al. 2011:26; ECB, 2010c:68). With the measures taken in the first phase of the crisis, the ECB aimed to keep the short term interest rate close to the monetary policy interest rate, rebuild the confidence in the economy, and thereby making the monetary market functional (ECB, 2015a:11). Indeed, the measures taken then kept short-term market interest rates close to monetary policy interest rates (Trichet, 2010:10). 


\section{IV.2. Financial Crisis (2008 September - 2010 May Period)}

Liquidity was injected into the market as a response to the liquidity shortage, which was a serious problem before the collapse of the Lehman Brothers. The liquidity crisis in the first phase of the financial crisis left its place to a confidence crisis in the second phase (Durré, et al. 2014:403). This was a result of the uncertainties about payment of the debt that started to emerge in the market after the collapse of the Lehman Brothers as the financial system had too many risk assets within itself (Claessens, et al. 2010:13). In this regard, the European Central Bank introduced non-standard monetary policy tools along with the standard ones following the collapse of the Lehman Brothers. In coordination with the central banks of other developed countries (Fed, Bank of England, Bank of Canada, Sveriges Riksbank, and the Swiss National Bank), the ECB decreased the short-term interest rates used as standard policy tools by 325 basis points in seven months (from October 2008 to May 2009), from $4.25 \%$ to 1.00\% (Fahr, et al. 2011: 27-28; Abbasi and Linzert, 2011:11; ECB, 2010a:65; Trichet, 2010:10-11).

Non-standard monetary policy tools were adopted to support the standard monetary policy tools and help the transmission of monetary policy to the economy (Giannone, et al. 2011:16). But, it is quite important to emphasize one point. It is out of the question for the ECB in particular to put non-standard monetary policy tools in effect after short-term interest rates fall to the lowest level, thereby loosing function. When short-term interest rates are set to ensure price stability, the transmission of the policy tool to the economy may not happen in case of a crisis. Non-standard monetary policy tools are used to make the transmission possible again. In other words, standard and non-standard monetary policy tools used in the Euro area are, to a great extent, independently determined. Standard policy tools are determined taking medium and long-term price stability into consideration. Non-standard monetary policy tools are adopted to activate the transmission mechanism (Trichet, 2013:231-232). Actually, non-standard monetary policy tools introduced by the ECB were implemented not to replace but to support the standard policy tools (Giannone, et al. 2011:5; Cour-Thimann and Winkler, 2013:20).

Non-standard monetary policy tools introduced by the ECB in addition to the standard monetary policy tools after September 2008 were the policy of enhanced credit support composed of five elements (ECB, 2010c: 68). The features specific to the Euro area were the reason for the implementation of this policy. Firstly, the banks make up the main source of finance in the Euro area when compared to the U.S. Secondly, there are a lot of small and medium sized firms dependent on bank credits in the Euro area. Finally, the wage and price of goods and services in the Euro area change more slowly (Trichet, 2009:89). 
The first element of enhanced credit support is fixed-rate allocation policy. With this policy, banks are provided with unlimited liquidity on adequate collateral at fixed rate for the refinancing operations (ECB, 2010c:68). These kinds of tendencies increase the demands of banks for liquidity from central bank. As a result, the European Central Bank's balance sheet expanded (Fahr, et al. 2010:53). The purpose of this policy is to keep the stress emerging in the banking system under control and provide households and firms with credits. It was not the European Central Bank that decided the amount of the liquidity provided to the banking system. In contrast, the market itself was given the opportunity to make the decision on the size of the intervention (Lenza, et al., 2010:314; ECB, 2009b:83). The second element is the expansion of the list of assets accepted as eligible collateral by the ECB. The purpose here is to implement the fixed-rate allocation policy as well as preventing collateral from causing any problem (ECB, 2009b:82). The third element is the extension of the maturity of refinancing operations from 3 months to 6 months. Then it was extended to one year. As a result, the banking system was provided with liquidity of 442 billion Euro in June, 2009 (Trichet, 2009:13). The goal of this operation was to make banks less dependent on short-term financing (Giannone, et al. 2011:14). The fourth element was the liquidity provision of foreign currency to help banks fund their foreign currency assets. The aim was to help prevent banks operating in the Euro area from having a problem of funding their assets denominated in U.S. dollar (Trichet, 2010:13). The fifth element is the covered bond purchase programme. Covered bond market is the main source of finance for most banks operating in the Euro area. With the collapse of this market following the financial crisis, the European Central Bank announced that they would purchase covered bond of $€ 60$ billion over 12 months from May 2009 to June 2010. Covered bonds are long term debt securities exported by banks and used for long-term refinancing operations. The goal of the program is to enliven the markets in short of liquidity and give banks an opportunity to resolve the mismatch between asset and liability accounts (Trichet, 2010:13; Trichet, 2009:14). In their study, Beirne, et al. (2011) stated that this program that was put in effect contributed to decreasing money market interest rates, reducing the funding cost of banks, helping them give more credits, and overcoming the liquidity shortage in debt securities market. However, they also emphasized that the sovereign debt crisis led the program not to function properly in some countries particularly.

In 2009, the fluctuation in the money markets slow down; the economy started to recover slowly though; the financial market conditions began to give positive signals. The non-standard policies fulfilled the expected function. In this regard, the ECB announced that they would gradually remove these policies after the financial system started to normalize (Fahr, et al. 2010:57; Cassola, et al. 2010:9; ECB, 2010a:70-71). 


\section{IV.3. Sovereign Debt Crisis (2010 May - 2014 June Period ${ }^{1}$ )}

During two previous periods, the ECB came across problems similar to those of other central banks had (Drudi, et al. 2012:3). However, the focus of the global financial crisis slid into the Euro area in the third phase of the crisis (Trichet, 2013:237). Falling growth rates, decreasing tax rates, and increasing social expenses after the financial crisis caused the countries to have more budgetary problems (Fawley and Neely, 2013:72). After the collapse of the Lehman Brothers, there were such incentives as state guarantees and capital injections provided by the countries in the Euro area to support the banking sector. As a result of these measures, in early 2010, some uncertainties started to emerge on financing the public debts of some countries in the sovereign bond markets within the Euro area (Drudi, et al., 2012:9). Some countries in the Euro area had increasing public debts and faced the challenge of sustaining these debts, and their credit ratings were downgraded because of the increase in the sovereign risk spreads, all of which contributed to emerging uncertainties (EC, 2009:44).

Table 1. Long-term Foreign Currency Sovereign Ratings in Some Euro Area Countries

\begin{tabular}{|l|l|l|l|l|}
\hline Country & Credit Rating in $\mathbf{2 0 0 7}$ & $\begin{array}{l}\text { When the credit rating was } \\
\text { downgraded }\end{array}$ & Credit Rating in 2009 & Outlook \\
\hline Greece & A & December 17, 2009 & BBB+ & Negative \\
\hline Ireland & AAA & June 8, 2009 & AA & Negative \\
\hline Spain & AAA & January 19,2009 & AA+ & Stable \\
\hline Portugal & AA- & January 21, 2009 & A+ & Stable \\
\hline
\end{tabular}

Source: Attinasi, et al. (2010: 38).

The process that started when some doubts emerged about the financing of public debts in Greece started to influence Ireland and Portugal in mid-2010. This process also affected Spain but to some extent. The credit rating of Greece and Ireland was downgraded BBB+ and AA in 2009, and the outlook turned negative for both countries. The credit rating of Spain and Portugal changed to AA+ and A+, making the outlook stable. All these developments destroyed the transmission channel again, which had actually started to recover (Cassola, et al. 2010:10-11). As a result, the ECB put the Securities Markets Programme into effect on 10 May 2010. The purpose of this programme is to restore the dysfunctional market segments by injecting liquidity to the debt securities markets and make the monetary transmission mechanism functional again (Trichet, 2013:237).

1 The purpose of the non-standard monetary policies implemented by the ECB before June 2014 was to overcome the troubles experienced in the monetary transmission mechanism. The purpose of those implemented after June 2014, though, was to provide more monetary convenience as well as improving the monetary transmission mechanism (ECB, 2015b: 1-2 ; ECB, 2015a: 15). Those policies are not within the scope of the period analyzed in this article. To have more information about those policies, please see ECB (2015b). 
The monetary policy measures taken and the bank rescue packages implemented by governments tried to repair the destruction caused by the financial crisis. However, the financial structures of countries entering the financial crisis with already distorted structure deteriorated with rescue packages. Moreover, as the investors lost their trust for risky financial assets and after path-finder tried they moved to low gains but safe government bonds. While choosing government bonds, the investors based their choices on the creditworthiness of countries and the liquidity of bond markets (Attinasi, et al. 2010:35-39). In this case, the biggest fluctuation in sovereign bond spreads was observed in countries facing the financial crisis with worse financial conditions (ECB, 2009c:37). This can be obviously seen in the figure below. The biggest fluctuation in sovereign bond spreads was observed in Greece, followed by Portugal and Ireland. Actually, Ejsing and Lemke (2009) analyzed bank and sovereign credit risk premiums in ten countries within the Euro area between January 2008 and June 2009. They stated that the risk premiums of banks decreased but the sovereign risks increased after most governments announced their bank rescue packages in October 2008. This was attributed to the change in the perception of investors about the credit risk: a risk transfer from the banking sector to public sector.

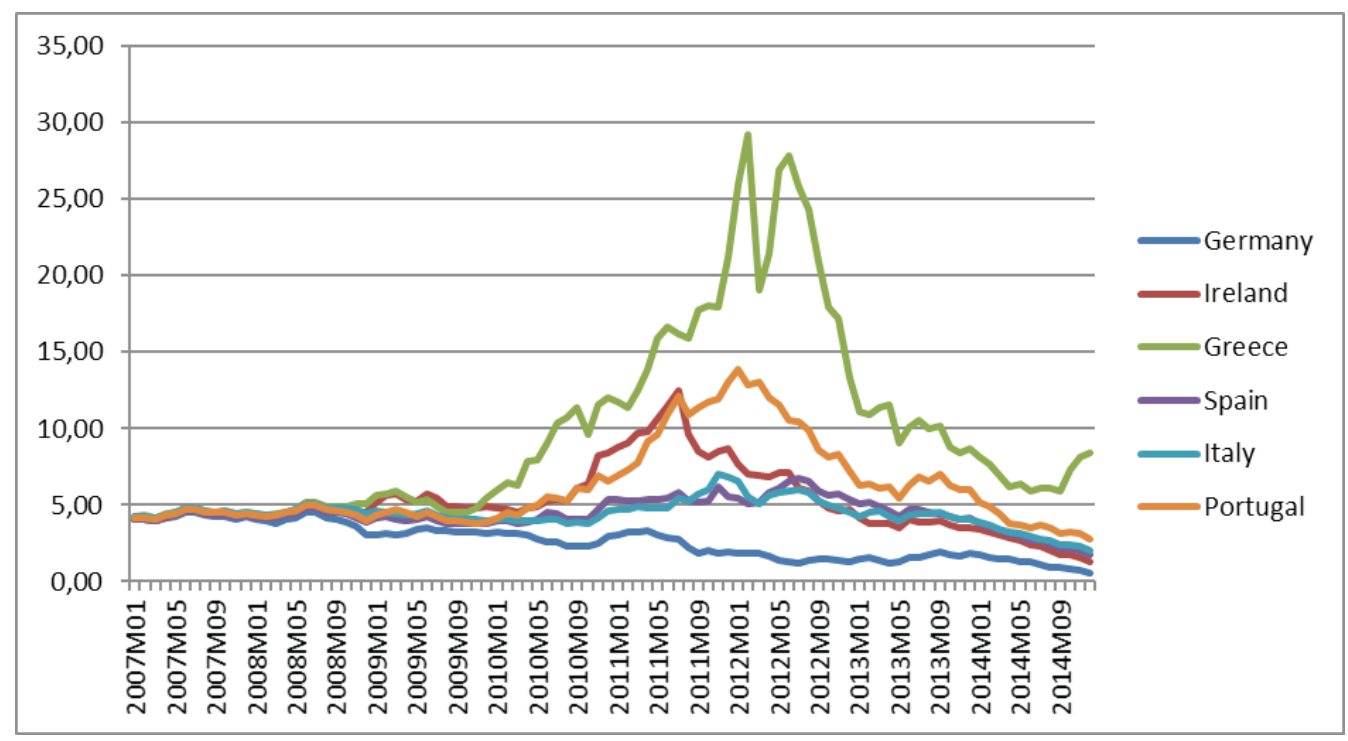

Figure 2. Sovereign Bond Yields (10-year maturity)

Source: Eurostat

Initially focusing on the debt securities of Greece, Ireland, and Portugal, the Securities Market Programme was expanded to cover the debt securities of Italy and Spain in August 2011. 
In early 2012 when the market conditions started to recover, the ECB stopped bond purchase. $€ 220$ billion of sovereign bonds were purchased by the ECB from countries in financial stress in February 2012 (Fratzscher, et al, 2014:6). The Securities Markets Programme, however, was not very effective because of the perception that the decisions of the ECB were made aversely (De La Dehesa, 2013:48). Moreover, the second Covered Bond Purchase Programme (CBPP2), exceeding $€ 40$ billion, was put into effect. But, it should be noted that the most important measure was the Outright Monetary Transactions ${ }^{2}$ (OMT) programme announced on September 6, 2012 (Rodríguez and Carrasco, 2014:11). The purpose of the programme was to make the monetary transmission mechanism functional again and provide homogenous credit terms within the Euro area (Szczerbowicz, 2015:102). The most essential element of the programme was that it included the phrase "unlimited". After the announcement of the programme, the government bound spreads within the Euro area dramatically decreased (Peersman, 2014:34). Also, the ECB implemented two LTROs (three year Long-Term Refinancing Operations) in December 2011 and February 2012 with intent to enhance the liquidity conditions of banks (Pattipeilohy, et al., 2013:18). With these two operations, the banks ran into debt of more than $€ 1$ trillion. All this process resulted in the expansion of the balance sheet of the ECB (Peersman, 2014:11). The figure below shows that the balance sheet of the ECB expanded particularly in 2012 after the introduction of the non-standard monetary policies.

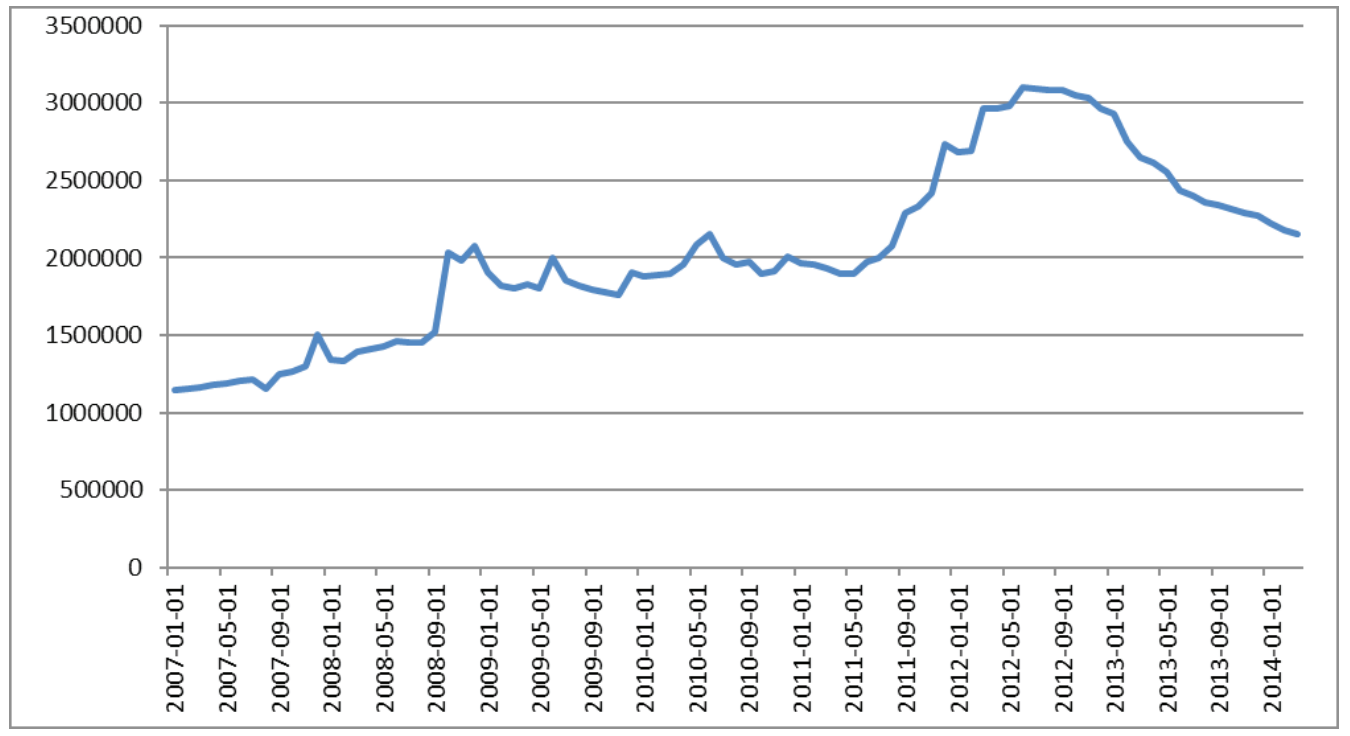

Figure 3. ECB Balance Sheet (Total Assets / Billion Euros)

Source: European Central Bank

2 Although the programme was announced, it was not put into effect (Rodríguez and Carrasco, 2014: 11). 
Another non-standard monetary policy tool used by the ECB is forward guidance. A strategy for giving information about the future monetary policies of central banks in advance, forward guidance was adopted by the ECB later than by the central banks of developed countries like the Fed, the Boj, and the Bank of England (Shirai, 2013:4). The forward guidance was introduced by the European Central Bank on July 4, 2013. The Governing Council of the ECB announced that:

The Governing Council expects the key ECB interest rates to remain at present or lower levels for an extended period of time. This expectation is based on the overall subdued outlook for inflation extending into the medium term, given the broad-based weakness in the real economy and subdued monetary dynamics (ECB, 2013).

The forward guidance adopted by the ECB is an example of open-ended forward guidance. However, as argued by Praet (2013 30-31) the open-ended forward guidance implemented by the ECB includes both "Delphic" and "Odyssean" features ${ }^{3}$. It includes Delphic features as the monetary policy that will be pursued by the ECB in the future is based on the current information. It includes Odyssean features as it states that it will stick to the European Central Bank's aim to keep inflation rate close to or below 2 percent over the medium-term and that it will go on taking the necessary measures to achieve this goal.

Open-ended forward guidance has given for qualitative information to market participants on the expected future path of policy rate (Bank of England, 2013:21). But, it is uncertain in open-ended forward guidance under which conditions the policy will be tightened or when it will come to an end (Carney, 2013:15). Despite having an advantage of giving central banks flexibility for unexpected conditions, implementing such a policy is disadvantageous in terms of providing the public with inadequate and uncertain information (Bank of England, 2013:21). As stated by Rodríguez and Carrasco (2014:12), the forward guidance adopted by the ECB made the policy less effective because of such factors as not including a specific time period or not setting threshold values on certain variables.

\section{THE IMPACT OF FISCAL CONDITION ON MONETARY POLICY}

Although non-standard monetary policy measures taken in response to sovereign debt crisis were good at calming down the markets, it is not possible for them to resolve crises because of their inherent structure (Eijffinger and Hoogduin, 2012:36). The policies implemented by the ECB are not specific to one single country as observed in other countries (US, Japan, Canada) (De La Dehesa, 2013:52). The monetary policy in the Euro area is

3 In the work of Campbell, et al. (2012), forward guidance is classified as "Delphic" and "Odyssean". According to this classification, the forward guidance of central banks that does not include commitment is called "Delphic" while the forward guidance that involves commitment is called "Odyssean" forward guidance. 
implemented by the ECB. The fiscal policy, though, is implemented by the governments of countries. Against the negative spillover effects of the fiscal policy of one country on the others, the rules of implementing national fiscal policies in the Euro area are based on the Stability and Growth Pact (SGP). The Maastricht Treaty in 1992 laid the foundations for the Stability and Growth Pact (Eyraud and Wu, 2015:5). According to the Maastricht criteria, the budget deficit of a member country is not to exceed 3 percent of its GDP and 60 percent of the ratio of its public debt to its GDP (EC, 2013:7).

The European debt crisis revealed the need for better-founded public financing. Prior to the financial crisis, the member countries that fell into the European debt crisis were not able to use the high growth rates they achieved to strengthen their budgetary positions (EC, 2013: 11). In Greece, for instance, its entry into the Economic and Monetary Union to the outbreak of the crisis (2001-2008) which was called the "golden age" of Greek economy, growth rates increased; unemployment decreased; the inflation rate was kept down although it was above the Euro area average. Despite these improvements, a positive progress was not achieved in terms of overcoming the fiscal problems. Although the ratio of public debt to GDP was stabilized at about $100 \%$, this rate was still quite above the Euro area average (Alogoskoufis, 2012:11). In Ireland, which was the second most severely affected country by the European debt crisis, the interest rates were low after joining the monetary union, and land and housing investments were mostly financed by the banking system via shortterm foreign funds, especially after 2003. The liquidity shortage that emerged in the international markets following the crisis left the banking system in a difficult situation and made the financial sector more fragile (Honohan, 2010:136; Honohan, 2009:2). Prior to the crisis, even though the ratio of public debt to GDP was below the Maastricht level, the bank rescue packages introduced as well as the public debt stock that remarkably increased, caused more concerns about the Irish economy. There was a partly similar situation in Spain (Eijffinger and Hoogduin, 2012:32). In Portugal, the financial loss resulting from the state-owned enterprises increased the public debt stock (Blanchard, et al. 2013:12). The table below shows how the ratio of public debts to GDP changed for the countries that went through the European sovereign debt crisis. 


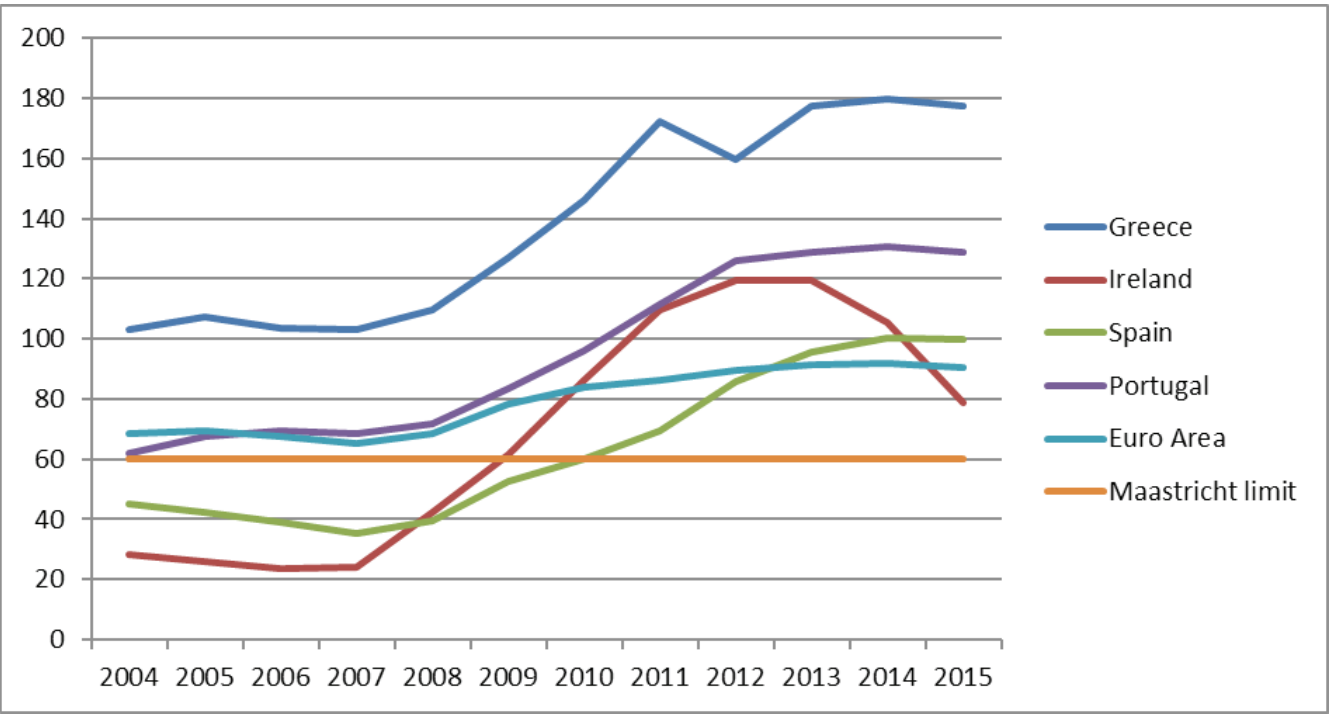

Figure 4. Government Debt (\% GDP)

Source: Eurostat

It can be seen that the budget deficit exceeded the Maastricht Criteria in the countries that faced the European debt crisis following the 2008 crisis. For example, the budget deficit in Greece was always above the Maastricht level after adopting Euro, but this did not cause a problem until 2009. However, the early election held in October 2009 ended with the victory of a socialist party led by Papandreu, resulting in a governmental reshuffle. The new government announced that the budget deficit in Greece was 12,7 percent of the GDP for 2009 (Arghyrou and Tsoukalas, 2011:174). The investors were concerned because this figure was almost two times more than the one announced by the previous government, and the Greek government admitted that the budget deficit figures announced earlier would not be accurate (Oxford Economics, 2010). Similarly, Portugal already had a budget deficit problem before the financial crisis, but it deepened in the aftermath. The collapse of the construction activity in Ireland led to a decrease in the gains from tax revenues. When the world economy faced a deep recession in September 2008, the economy contracted by $-6,4$ in 2009, and the budget surplus achieved in many years suddenly turned into budget deficit (Whelan, 2011:7). 


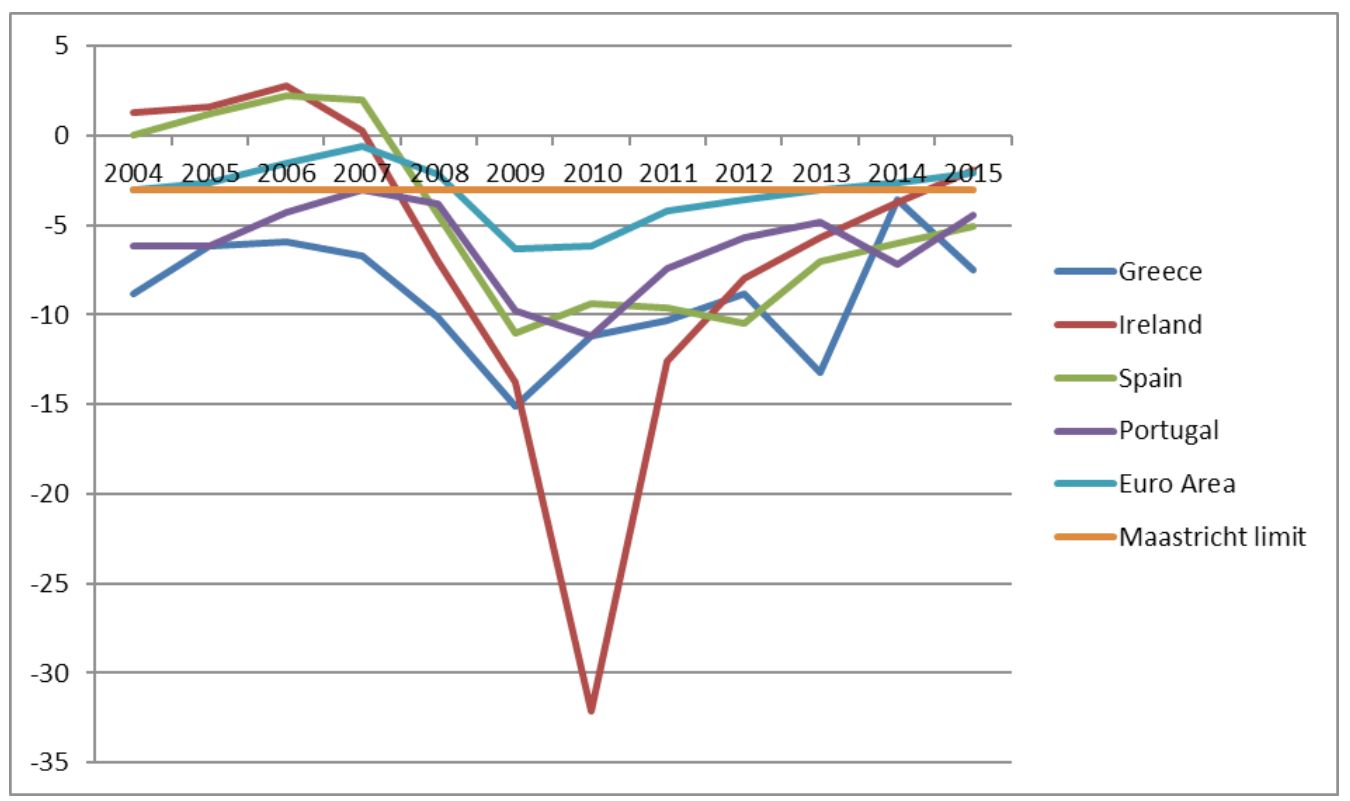

Figure 5. Government Deficit/Surplus

Source: Eurostat

As a response to these weaknesses, rules known as 'Six-pack' were set for the fiscal policy in the aftermath of the European debt crisis ${ }^{4}$ (EC, 2013:11-12). The European debt crisis showed us the following: the crisis of the sustainability of the fiscal structure in some countries of the Euro area began to endanger the financial stability in the Euro area because of the high integration and the risk of contagion among the countries (Eijffinger and Hoogduin, 2012:32). This leads us to the following conclusion: If countries build enough fiscal buffers when their economies go smoothly, they may have a higher capacity of responding and preventing the shocks to occur during an economic crisis. But the countries of the Euro area especially the peripheral ones were not fiscally strong enough to prevent big shocks when the crisis began (Eyraud and Wu, 2015:9).

\section{CONCLUSION}

Most central banks introduced non-standard monetary policy tools after the collapse of Lehman Brothers which were appropriate to their own financial systems in order to ensure monetary policy transmission. During this period, the ECB also implemented non-standard monetary policies along with the standard policy tools just as other central banks of

4 See EC 2013 for further information. 
developed countries (like Fed, Bank of England) did. However, it is important to take some specific points into consideration while evaluating the monetary policies of the ECB in particular. Firstly, the policies adopted by the ECB were not specific to one single country. Secondly, the policies implemented were prepared by considering the factor that the banking system was the major source of financing in Europe. This study analyzes the monetary policy measures taken by the European Central Bank according to specific periods. The first period corresponds to the time just after the crisis, and the characteristic feature of this period is that the European Central Bank tried to find a solution to the crisis by providing liquidity to the market as there was liquidity crunch in the interbank monetary market. This period, 2007 August - 2008 September, gained a new dimension with the collapse of Lehman Brothers. Besides the shortage of liquidity, some uncertainties also emerged on the banks' potential for repaying their debts. During the second period covering September 2008 - May 2010, the European Central Bank introduced non-standard monetary policy tools as well as decreasing the policy interest rates. Indeed, these policies had an impact on eliminating the uncertainties in the financial markets. The financial crisis in the Euro area, however, turned into a sovereign debt crisis in 2010. The bank rescue packages introduced by the countries after the collapse of Lehman Brothers were perceived by investors as a transfer of credit risk from the banking sector to the public sector. This caused a fluctuation in long-term government bond yields in the countries that entered the crisis with an already deteriorated financial structure and in the countries whose financial structure deteriorated after the outbreak of the crisis. During the third period covering the time after May 2010, the Securities Markets Programme was firstly introduced. The program was expanded to cover the debt securities of Italy and Spain in August 2011. In addition, two LTROs were introduced in December 2011 and February 2012.

Offering a descriptive analysis of the non-standard monetary policies implemented by the ECB after the crisis, this study helps draw the following conclusions. The reason why the ECB implemented non-standard monetary policies except for the forward guidance during the period analyzed (between August 2007 and June 2014) was different from that of other central banks. They introduced non-standard policy tools after the standard monetary policy tools lost their function. The ECB, though, introduced those policy tools to help the transmission mechanism deteriorated in time become functional again and to support the standard monetary policy tools. Also, the policies implemented by the ECB were not specific to one single country because of its institutional structure, which was unlike the case in other countries (US, Japan, Canada). Since its foundation, the ECB has focused on the policies appropriate to be implemented in all member countries. The fiscal policy, though, does not have such central features, and it is implemented by national governments. Although there are some general policy frameworks like Stability Growth Pact, they have generally been regarded as loose principles. It was not seen as a problem to loosen such framework principles 
especially before the crisis. But the breakout of the crisis showed the need to pay more attention to heterogeneous features of the countries' fiscal policies and to the problems resulting from the countries' different policy contexts. Another important conclusion to be drawn about monetary policies during a crisis is that having an inadequate fiscal buffer- even if such common standards exist- has a decisive role in the response to crises faced. Despite the similar policy frameworks, the difference between the EU countries having a strong fiscal buffer and those lacking it indicates the importance of having strong fiscal structure during a crisis. If countries build adequate fiscal buffers when their economic conditions are good, they have more capacity to respond and to prevent the shocks faced during an economic crisis. Indeed, having a strong fiscal structure gives them more room to maneuver in the policies to be adopted during a crisis. The conclusion to be drawn from the experience of harmonizing the fiscal systems that do not have homogeneous features during that period is that budgetary and fiscal conditions have a key role in determining effective monetary policies. Therefore, general economic factors may have complicated impacts on shaping the expected results of policies when there are various implementations of monetary policies.

\section{References}

Abbassi, P. and Linzert, T. (2011). The Effectiveness of Monetary Policy in Steering Money Market Rates During the Recent Financial Crisis. Working Paper Series, No.1328, European Central Bank, (http://www.ecb.europa.eu/pub/pdf/scpwps/ecbwp1328.pdf (10 May 2013).

Alogouskoufis, G. (2012). Greece’s Sovereign Debt Crisis: Retrospect and Prospect, Hellenic Observatory European Institute, http://eprints.lse.ac.uk/42848/1/GreSE\%20No54.pdf (04 April 2014).

Altunbaş, Y. Gambacorta, L. and Marques-Ibanez D. (2009). Securitisation and the Bank Lending Channel. European Economic Review, 53, 996-1009.

Arghyrou, M, G. and Tsoukalas J. D. (2011). The Greek Debt Crisis: Likely Causes, Mechanics and Outcomes, The World Economy, 34(2), 173-191.

Attinasi, G.M., Checherita, C. and Nickel, C. (2010). Euro Area Fiscal Policies and the Crisis: The Reaction of Financial Markets. (ed. Riet, A.) Euro Area Fiscal Policies and the Crisis, Working Paper Series, No.109, European Central Bank, (http://www.ecb.int/pub/pdf/ scpops/ecbocp109.pdf (15 April 2011).

Bank of England. (2013). Monetary policy trade-offs and forward guidance.(August). (http://www.bankofengland.co.uk/publications/Documents/inflationreport/2013/ ir13augforwardguidance.pdf (10 June 2014).

Beirne, J., Ejsing, J., Grothe, M., Manganelli, S., Monar, F., Sahel, B., Susec, M., Tapking, J. and Vong, T. (2011). The Impact of The Eurosystem's Covered Bond Purchase Programme 
on the Primary and Secondary Markets. Working Paper Series, No.122, European Central Bank, (http://www.ecb.europa.eu/pub/pdf/scpops/ecbocp122.pdf (10 April 2012).

Bernanke, B. S. and Blinder, A. S. (1988). Credit, Money and Aggregate Demand. The American Economic Review, 78(2), 435-439.

Bernanke, B. S. and Blinder, A. S. (1992). The Federal Funds Rate and the Channels of Monetary Transmission. The American Economic Review, 82(4), 901-921.

Bernanke, B.S. and Gertler, M. (1995). Inside the Black Box: the Credit Channel of Monetary Policy Transmission. Journal of Economic Perspective, 9(4), 27-48.

Blanchard, O., Dell'Ariccia, G. and Mauro, P. (2013). Rethinking Macro Policy II: Getting Granular, Staff Discussion Note 13/03, IMF,( https://www.imf.org/external/pubs/ft/ sdn/2013/sdn1303.pdf (05 June 2015).

Boeckx, J., Dossche, M. and Peersman, G. (2014). Effectiveness and Transmission of the ECB's Balance Sheet Policies. Working Paper Research, No. 275. (http://aei.pitt.edu/63428/1/ WP275En.pdf (25 May 2015).

Campbell, J.R, Evans, C.L., Fisher, J.D. and Justiniano A. (2012). Macroeconomic Effects of Federal Reserve Forward Guidance, Working Paper No. 2012-03, Federal Reserve Bank of Chicago.

Carney, M. (2013). Monetary Policy After the Fall. Eric J. Hanson Memorial Lecture, University of Alberta, Edmonton, Alberta.

Cassola, N., Durre, A., and Holthausen, C. (2010). Implementing Monetary Policy in Crisis Times: The case of the ECB/Eurosystem. ECB Central Banking Conference, Frankfurt, November.

Cecchetti, S.G. (1995). Distinguishing Theories of the Monetary Transmission Mechanism. Federal Reserve Bank of St.Louis Economic Review, May/June, 83-97.

Cecioni, M., Ferrero, G., and Secchi, A. (2011). Unconventional Monetary Policy in Theory and in Practice. Banca D’ITALIA, Eurosistema, Number 102, (http://www.bancaditalia.it/ pubblicazioni/econo/quest_ecofin_2/QF_102/QEF_102.pdf(05.January 2014).

Claessens, S.. Dell'Ariccia, G., Igan, D., and Laeven, L. (2010). Lessons and Policy Implications from the Global Financial Crisis. IMF Working Paper, WP/10/44, (http://www.imf.org/ external/pubs/ft/wp/2010/wp1044.pdf (02.February 2013).

Cour-Thimann, P. and Winkler, B. (2013). The ECB's Non-Standard Monetary Policy Measures the Role of Institutional Factors and Financial Structure. Working Paper Series, No.1528, European Central Bank, (http://www.ecb.europa.eu/pub/pdf/scpwps/ecbwp1528.pdf 22 April 2014).

Darracq-Paries, M. and De Santis, R. (2013). A Non-Standard Monetary Policy Shock The ECB's 3-Year LTROs And the Shift in Credit Supply, Working Paper Series, No.1508, European 
Central Bank, (https://www.ecb.europa.eu/pub/pdf/scpwps/ecbwp1508.pdf (15 April 2014).

De La Dehesa, G. (2013). Non-Standard and Unconventional Monetary Policy Measures. NonStandard Monetary Policy Measures-An Update, European Parliament Directorate General for International Policies Policy Department, 43-54.

Drudi, F., Durre, A. and Mongelli, F.P. (2012). The Interplay of Economic Reforms and Monetary Policy the Case of the Euro Area. Working Paper Series, No.1467, European Central Bank, (http://www.ecb.europa.eu/pub/pdf/scpwps/ecbwp1467.pdf (05 January 2014).

Durré, A., Maddaloni, A., and Mongelli, F.P. (2014). The ECB’s Experience of Monetary Policy in a Financially Fragmented Euro Area. Comparative Economic Studies, 56, 396-423.

European Commission (2009). Economic Crisis in Europe: Causes, Consequences and Responses. (http://ec.europa.eu/economy_finance/publications/publication15887_en.pdf (15 April 2011).

European Commission, (2013). Building a Strengthened Fiscal Framework in the European Union: A Guide to the Stability and Growth Pact," Occasional Papers 150.

ECB. (2008.) The Role of Banks in the Monetray Policy Transmission Mechanism. Monthly Bulletin, August.

ECB. (2009a.) Monetary Policy and Loan Supply in the Euro Area. Monthly Bulletin, October.

ECB. (2009b.) The Implementation of Monetary Policy since August 2007. Monthly Bulletin, July.

ECB (2009c). How have Governments' Bank Rescue Packages Affected Investors' Perceptions of Credit Risk?. Monthly Bulletin, March.

ECB. (2010a). The ECB's response to the financial crisis. Monthly Bulletin, October.

ECB. (2010b). Monetary Policy Transmission in the Euro Area, A Decade after the Introduction of the Euro. Monthly Bulletin, May.

ECB. (2010c.) The ECB's Monetary Policy Stance During the Financial Crisis. Monthly Bulletin, January.

ECB. (2011). The ECB's Non-Standart Measures-Impact and Phasing-Out. Monthly Bulletin, July.

ECB. (2013). Introductory statement to the press conference (with Q\&A), (https://www.ecb. europa.eu/press/pressconf/2013/html/is130704.en.html (10 June 2014).

ECB (2015a). The Role of the Central Bank Balance Sheet in Monetary Policy. Economic Bulletin, Issue 4.

ECB (2015b). The Transmission of the ECB’s Recent Non-Standard Monetary Policy Measures. Economic Bulletin, Issue 7.

Eijffinger, S. and Hoogduin, L. (2012). The European Central Bank in (the) Crisis. CESifo DICE Report 1. 
Egert, B. and MacDonald, R. (2009). Monetary Transmission Mechanism in Central and Eastern Europe: Surveying the Surveyable. Journal of Economic Surveys, 23(2), 277-327.

Ejsing, Jacop, W. and Lemke, W. (2009). The Janus-Headed Salvation Sovereign and Bank Credit Risk Premia During 2008-9. Working Paper Series, No.1127, European Central Bank, (http://www.ecb.europa.eu/pub/pdf/scpwps/ecbwp1127.pdf (5 May 2011).

Eser, F. and Schwaab, B. (2016). Evaluating the impact of unconventional monetary policy measures: Empirical evidence from the ECB’s Securities Markets Programme. Journal of Financial Economics, 147-167.

Eyraud, L. and Wu, T. (2015). Playing by the Rules: Reforming Fiscal Governance in Europe, IMF Working Paper, WP/15/67. (https://www.imf.org/external/pubs/ft/wp/2015/wp1567.pdf (02 January 2017).

Fahr, S., Motto, R., Rostagno, M., Smets, F. and Tristani, O. (2010). Lessons for Monetary Policy Strategies from the Recent Past. (http://www.ecb.int/events/conferences/html/ cbc6/2fahrmottorostagnosmetstristani6cbc.pdf (05 May 2011).

Fahr, S., Motto, R., Rostagno, M., Smets, F. and Tristani, O. (2011). A Monetary Policy Strategy in Good and Bad Times Lessons from the Recent Past. Working Paper Series, No.1336, European Central Bank, (http://www.ecb.europa.eu/pub/pdf/scpwps/ecbwp1336.pdf (14 February 2013).

Fawley, Brett W. and Neely Christopher J. (2013). Four Stories of Quantitative Easing. Federal Reserve Bank of St. Louis REVIEW, pp. 51-88.

Fratzscher, M., Lo Duca, M. and Straub, R. (2014). ECB Unconventional Monetary Policy Actions: Market Impact, international Spillovers and Transmission Channels, 15TH JACQUES POLAK ANNUAL RESEARCH CONFERENCE, (https://www.imf.org/external/np/res/ seminars/2014/arc/pdf/fratzscher_loluca_straub.pdf (05 June 2015).

Giannone, D., Lenza, M., Pill, H. and Reichlin, L. (2011). Non-Standart Monetary Policy Measures and Monetary Developments. Working Paper Series, No.1290, European Central Bank, (http://www.ecb.int/pub/pdf/scpwps/ecbwp1290.pdf (05 April 2013).

Honohan, P. (2009). What Went Wrong in Ireland?, http://homepage.eircom.net/ phonohan/ What\%20went\%20wrong.pdf, (30 June 2014).

Honohan, P. (2010). Euro Membership and Bank Stability-Friends or Foes? Lessons from Ireland, Comparative Economic Studies, 52, 133-157.

Lane, P.R. (2012). The European Sovereign Debt Crisis. Journal of Economic Perspectives, 26(3), 49-68.

Lenza, M., Pill, H. and Reichlin, L.,(2010). Monetray Policy in Exceptional Times. Economic Policy, 25(4), 295-339.

Oxford Economics (2010). Is Greece Heading for Default?, http://www.oxfordeconomics.com/ publication/download/214082, (01 January 2013). 
Pattipeilohy, C., van den End, J.W., Tabbae, M., Frost, J. and de Haan, J. (2013). Unconventional Monetary Policy of the ECB during the Financial Crisis: An Assessment and New Evidence. DNB Working Paper No. 381, (http://www.dnb.nl/binaries/Working\%20Paper\%20381_ tcm46-291731.pdf (25 May 2014).

Peersman, G. (2011). Macroeconomic Effects of Unconventional Monetary Policy in the Euro Area. Working Paper Series, No.1397, European Central Bank, (http://www.ecb.europa.eu/ pub/pdf/scpwps/ecbwp1397.pdf (05 April 2013).

Peersman, G. (2014). The Effectiveness of Unconventional Monetary Policies. Working Paper, 2014/875, (http://wps-feb.ugent.be/Papers/wp_14_875.pdf (03 January 2015).

Praet, P. (2013). Forward Guidance and the ECB, Forward Guidance: Perspectives from Central Bankers, Scholars and Market Participants, (eds. den Haan,W.), London: Centre for Economic Policy Research (CEPR), 25- 34.

Rodríguez, C. and Carrasco, C.A. (2014). ECB Policy Responses between 2007 and 2014: a chronological analysis and a money quantity assessment of their effects. Financialisation, Economy, Society and Sustainable Development, Working Paper Series, No 65. (http:// fessud.eu/wp-content/uploads/2013/04/ECB-policy-responses-RodriguezCarrasco_ Working-paper-65.pdf (05 January 2015).

Scheller, H. K. (2006). The European Centrel Bank History, Role and Functions. European Central Bank.

Shirai, S. (2013). Monetary Policy and Forward Guidance in Japan. speech at the International Monetary Fund and the Board of Governors of the Federal Reserve System held in Washington, D.C., Bank of Japan, (https://www.boj.or.jp/en/announcements/press/ koen_2013/data/ko130921a1.pdf (20 June 2014).

Szczerbowicz, U. (2015). The ECB Unconventional Monetary Policies: Have They Lowered Market Borrowing Costs for Banks and Governments?, International Journal of Central Banking, 11(4), 91-127.

Taylor, J.B. (1995). The Monetary Transmission Mechanism: An Empirical Framework. The Journal of Economic Perspectives, 9(4), 11-26.

Thornton, D.L. (2012). The Federal Reserve's Response to the Financial Crisis: What It Did and What It Should Have Done. Federal Reserve Bank of St.Louis Working Paper Series, Working Paper 2012-050A, (http://research.stlouisfed.org/wp/2012/2012-050.pdf 03 March 2013).

Trichet, J.C. (2009). The ECB's Enhanced Credit Support. Keynote address at the University of Munich/IFO symposium, (http://papers.ssrn.com/sol3/papers.cfm?abstract_id=1500267 (05 May 2011).

Trichet, J.C. (2010). State of the Union: The Financial Crisis and the ECB's Response between 2007 and 2009. Journal of Common Market Studies, 48, 7-19. 
Trichet, J.C. (2013). Unconventional Monetary Policy Measures: Principles-Conditions-Raison d'être. International Journal of Cenrtal Banking, 9(1), 229-250.

Whelan, K. (2011). Ireland's Sovereign Debt Crisis, UCD Centre for Economic Research Working Paper Serises, WP11/09, http://www.ucd.ie/t4cms/WP11_09.pdf, (03 December 2013).

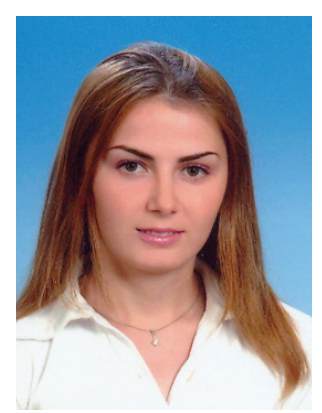

Meryem FILIIZ BAŞTÜRK - meryemfiliz@uludag.edu.tr

Recevied graduate degree at Uludag University, Department of Economics in 2003 also she has worked in same department since 2005 as an scholar. FILİZ BAŞTÜRK gained PhD. within "A Theorical and Empirical Study on the Efficiency of Monetary Transmission Mechanism in Turkey in 2012. Interested areas which is monetary theory and financial markets. 
